\title{
New fossil representative of the genus Helius (Diptera, Limoniidae) from the little known and newly discovered locality Caergen Village of northeastern Tibetan Plateau (China)
}

\author{
Siyuan Wu, Wiesław Krzemiński, Agnieszka Soszyńska-Maj, and Dong Ren
}

\begin{abstract}
Helius (Helius) qinghai $\mathrm{n}$. sp. belongs to the one of the best studied genera of the Diptera in terms of its history, with 23 fossil species described to date. The new species described in this paper is the first representative of the family Limoniidae (Diptera) from the little known and newly discovered locality Caergen Village from eastern Qinghai Province, northeastern Tibetan Plateau (China). The age range of fossils at Caergen Village of the Garang Formation is late Early Miocene to early Middle Miocene (16-19 $\mathrm{Ma})$. This finding contributes to our knowledge of the evolution of the genus Helius. A summary about fossil records of the genus Helius is presented in the paper.
\end{abstract}

Siyuan Wu. College of Life Sciences, Capital Normal University, Beijing 100048, China.

rendong@mail.cnu.edu.cn

Wiesław Krzemiński. Institute of Biology, Pedagogical University of Kraków, Podbrzezie 3, 31-054 Kraków, Poland. krzeminski@isez.pan.krakow.pl

Agnieszka Soszyńska-Maj. Department of Invertebrate Zoology and Hydrobiology, Faculty of Biology and Environmental Protection, University of Łódź, 90-237 Łódź, Poland. agnieszka.soszynska@biol.uni.lodz.pl Dong Ren. College of Life Sciences, Capital Normal University, Beijing 100048, China.

rendong@mail.cnu.edu.cn

Key words: fossil insects; morphology; Nematocera; new species; taxonomy

Submission: 6 September 2017 Acceptance: 17 December 2018

http://zoobank.org/709E2F42-00EA-4F51-8A69-3D03724978FD

Wu, Siyuan, Krzemiński, Wiesław, Soszyńska-Maj, Agnieszka, and Ren, Dong. 2019. New fossil representative of the genus Helius (Diptera, Limoniidae) from the little known and newly discovered locality Caergen Village of northeastern Tibetan Plateau (China). Palaeontologia Electronica 22.1.2A 1-8. https://doi.org/10.26879/817 palaeo-electronica.org/content/2019/2382-helius-qinghai-n-sp

Copyright: January 2019 Paleontological Society.

This is an open access article distributed under the terms of the Creative Commons Attribution License, which permits unrestricted use, distribution, and reproduction in any medium, provided the original author and source are credited.

creativecommons.org/licenses/by/4.0/ 


\section{INTRODUCTION}

Limoniid flies of the genus Helius Lepeletier and Serville, 1828, are characterized by a significantly elongated rostrum reaching almost body length in some species; all species have also a characteristic wing venation. Evolution of this genus is one of the best documented among the Diptera; 23 fossil species described to date (Table 1) cover the entire period of the genus' evolution since the Lower Cretaceous to the Lower Miocene - more than 130 million years (Kania et al., 2016). The first two fossil representatives were described by Loew (1850) from Eocene Baltic amber. The oldest members of the genus were found recently in Lebanon amber from the Lower Cretaceous (Kania et al., 2013; Krzemiński et al., 2014). From the Cretaceous three more species were described: in Burmese amber from mid-Cretaceous (Ribeiro, 2002), from the Upper Cretaceous of Botswana (Rayner and Waters, 1990) and from Cretaceous amber of Alava (Spain) (Kania et al.,
2016). However, majority of fossil Helius species were described from Eocene Baltic amber (Loew, 1850; Meunier, 1906; Alexander, 1931; Krzemiński, 1985, 1993; Kania et al., 2013; Krzemiński et al., 2014; Kania, 2014). From the Oligocene, two species are known from Europe (Statz, 1944), one from North America (Krzemiński, 1991) and three in Miocene Dominican and Mexican ambers from Central America (Podenas, 2002; Podenas and Poinar, 2001, 2012; Kopeć et al., 2016). Krzemiński (2002) described three other species from the Middle Miocene of Caucasus, $H$. stavropolensis, $H$. miocenicus and $H$. erticillis. Recently, more than 200 species of Helius occur on all continents except Antarctica (Oosterbroek, 2016).

In a little-known locality aged at the Lower Miocene of northeastern Tibetan Plateau (China), an assemblage of fossil plants and insects was discovered. The fossil described in this paper was collected from the Guide Group at Caergen Village,

TABLE 1. List of fossil species from the genus Helius with age and locality.

\begin{tabular}{|c|c|c|}
\hline Species & Age & Locality \\
\hline Helius miocenicus Krzemiński, 2002 & Middle Miocene & Stavropol, Caucasus, Russia \\
\hline Helius stavropolensis Krzemiński, 2002 & Middle Miocene & Stavropol, Caucasus, Russia \\
\hline Helius verticilis Krzemiński, 2002 & Middle Miocene & Stavropol, Caucasus, Russia \\
\hline Helius qinghai $n . s p$ & Lower Miocene & Caergen Village, China \\
\hline Helius collemus Podenas and Poinar, 2012 & Lower Miocene & Dominicana \\
\hline Helius neali Kopeć, Kania \& Krzemiński, 2016 & Lower Miocene & Dominicana \\
\hline Helius oosterbroeki Kopeć, Kania \& Krzemiński, 2016 & Lower Miocene & Dominicana \\
\hline Helius tenerus Statz, 1944 & Late Oligocene & Rott, Germany \\
\hline Helius weigandi, Statz, 1944 & Late Oligocene & Rott, Germany \\
\hline Helius constenius Krzemiński, 1991 & Oligocene & North Montana, USA \\
\hline Helius formosus Krzemiński, 1993 & Lower Eocene & Baltic Area \\
\hline Helius linus Podenas, 2002 & Lower Eocene & Baltic Area \\
\hline Helius minutus (Loew, 1850) & Lower Eocene & Baltic Area \\
\hline Helius mutus Podenas, 2002 & Lower Eocene & Baltic Area \\
\hline Helius pulcher (Loew, 1850) & Lower Eocene & Baltic Area \\
\hline Helius fossilis Kania, 2014 & Lower Eocene & Baltic Area \\
\hline Helius similis Kania, 2014 & Lower Eocene & Baltic Area \\
\hline Helius gedanicus Kania, 2014 & Lower Eocene & Baltic Area \\
\hline Helius hoffeinsorum Kania, 2014 & Lower Eocene & Baltic Area \\
\hline Helius botswanensis Rayner \& Waters, 1990 & Turonian (Cretaceous) & Orapa, Botswana \\
\hline Helius alavensis Kania, Krzemiński \&Arillo, 2016 & upper Albian (Cretaceous) & Alava, Spain \\
\hline Helius krzeminskii Ribeiro, 2002 & Cenomanian (Cretaceous) & Tanai village, Burma \\
\hline Helius lebanensis Kania, Krzemiński \&Azar, 2013 & Lower Cretaceous & $\begin{array}{l}\text { Tannourine, North Lebanon,Hammana, } \\
\text { Central Lebanon }\end{array}$ \\
\hline Helius ewa Krzemiński, Kania \& Azar, 2014 & Lower Cretaceous & Hammana, Central Lebanon \\
\hline
\end{tabular}


Duohemao Town, Zeku County, eastern Qinghai Province, Northwest China $\left(34^{\circ} 56^{\prime} \mathrm{N}, 101^{\circ} 48^{\prime} \mathrm{E}\right.$, $3700 \mathrm{~m}$ a.s.I.) (Li Y. et al., 2016; Li X. et al., 2016). The Guide Group constitutes a lacustrine-fluvial sedimentary terrain and is mainly concentrated in the basins of eastern Qinghai Province: XiningMinhe, Tongde, Guide-Hualong and Caergen (Guo, 1980, Fang et al., 2005). The outcrop is divided into five formations: the Ganjia Formation (2.6-3.6 Ma; Fang et al., 2005), the Herjia Formation (3.6-7.8 Ma), the Ashigong Formation (7.8 to $>11.5 \mathrm{Ma}$ ), the Garang Formation $(<16-19 \mathrm{Ma})$ and the Guidemen Formation (19-20.8 Ma). The exposed oil shale beds of the section belonging to the Garang Formation yield abundant, exquisitely preserved plants fossil (Guo, 1980), palynological fossils (Sun et al., 1984) and mammalian fossils (Qiu, 1981a, b). Insect fossils were collected from the Garang Formation and include Hemiptera, Hymenoptera, Mecoptera, Odonata and Diptera. The age range of fossils at Caergen Village is the late Early Miocene to early Middle Miocene, < 16$19 \mathrm{Ma}$. More details about geological settings are available in Li Y. et al. (2016) and Li X. et al. (2016). To date at this locality only three specimens of crane flies have been found, two from the family Tipulidae and one to the genus Helius from the Limoniidae.

The new fossil species of the genus Helius from this newly discovered locality is described here; this finding contributes to our knowledge of the evolution of the genus.

\section{MATERIAL AND METHODS}

The study was based on specimen No. CNUDIP-QZ2017001 from the Guide Group at Caergen Village, Duohemao Town, Zeku County, eastern Qinghai Province, North-west China from early Miocene (Figures 1-2), one and the only representative of genus Helius (Limoniidae) was found in this locality. Holotype is housed in the collection of the Key Laboratory of Insects Evolution and Environment Changes, College of Life Sciences, Capital Normal University, Beijing, China.

The specimen was studied using a Motic SMZ-168 stereomicroscope equipped with a Leica DFC 500 digital camera. The measurements were taken with NIS-Elements D 3.0 software. Line drawings were prepared with Adobe Illustrator CC and Adobe Photoshop Elements 5.0 graphics software. The length of $d$-cells was measured from the hind edge of $d$-cells to the connection of cross-vein $\mathrm{m}-\mathrm{m}$ with vein $\mathrm{M}_{3}$. The drawings for the analysis were based on the specimen and photographs.

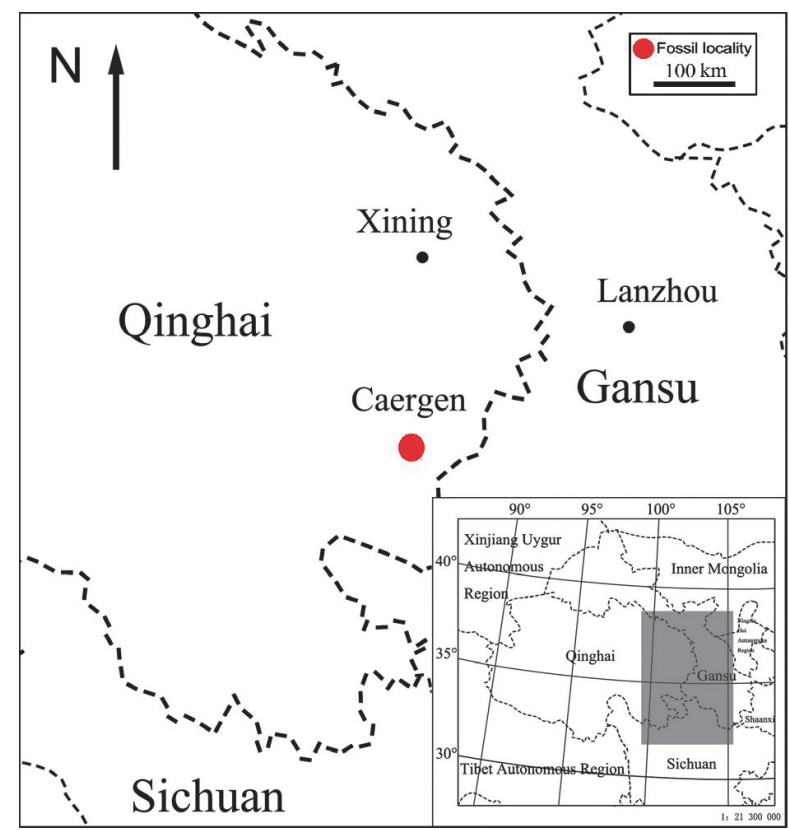

FIGURE 1. Map showing the location of the fossil site near Caergen Village.

Wing venation nomenclature follows Krzemińska et al. (2009).

\section{SYSTEMATIC PALAEONTOLOGY}

Order DIPTERA Linnaeus, 1758

Family LIMONIIDAE Speiser, 1909

Subfamily LIMONIINAE Speiser, 1909

Genus HELIUS Lepeletier and Serville, 1828

Type species. Limnobia longirostris Meigen, 1818 Subgenus. Helius Lepeletier and Serville, 1828

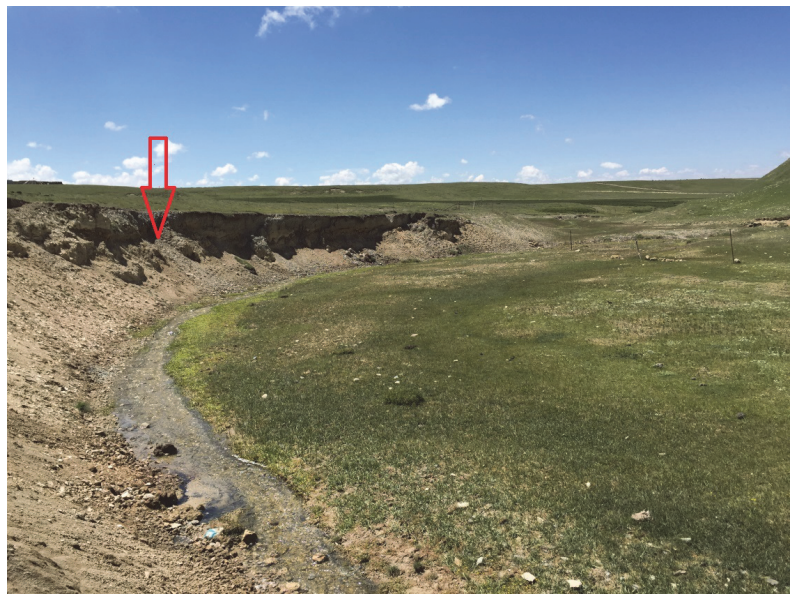

FIGURE 2. Vegetation surrounding Caergen Village and outcrops of the fossiliferous strata. Red mark is the fossil collection location, photo 24 Jul 2015. 
Type species. Limnobia longirostris Meigen, 1818

Helius (Helius) qinghai sp. nov. Wu and Krzemiński Figures 3-4

zoobank.org/AB485B8C-DFF7-4125-8C49-5D5747200027

Material. Holotype NO. CNU-DIP-QZ2017001, male, deposited in the collection of the Key Laboratory of Insects Evolution and Environment Changes, College of Life Sciences, Capital Normal University, Beijing, China.

Etymology. The species name is derived from the name of the province where specimen was found.

Age and occurrence. Garang Formation at Caergen Village, Duohemao Town, Zeku County, eastern Qinghai Province, north-west China, Early Miocene, 16-19 Ma.

Diagnosis. Last segment of palpus slightly shorter than all remaining segments combined together; rostrum only slightly longer than palpus; antenna almost twice as long as rostrum and two and a half times as long as head; vein $R_{2+3+4}$ is almost twice longer than vein Rs; $d$-cell is as long as $1 / 7$ of wing; hypopygium with short and broad gonocoxite, outer gonostylus strongly sclerotized, short, broad at base and gradually narrowing to distal part; inner gonostylus as long as outer one, lobe-shape.

Comparison. Helius ( $H$.) qinghai sp. nov. differs significantly from other fossil congenerics in the length of the rostrum and wing venation and from the only closely related species $H$. (H.) oosterbroeki Kopeć, Kania and Krzemiński, 2016, by the wing venation and male hypopygium. Vein $\mathrm{R}_{2+3+4}$ in $H$. (H.) oosterbroeki is very short, only about only a quarter longer than Rs, and Rs starts beyond cross vein sc-r, while in $H$. (H.) qinhghai sp. nov. vein $R_{2+3+4}$ is elongated, slightly curved and slightly less than twice as long as vein Rs, and Rs forks at the level of cross-vein sc-r. Moreover, dcell in $H$. (H.) oosterbroeki is rounder, while in $H$. (H.) qinghai sp. nov. is elongated. New species differs by the morphology of male genitalia, both gonostyli are equal in length and shape, while in $H$. $(H$.$) oosterbroeki outer gonostylus is much thinner$ and slightly longer than inner gonostylus.

Description. Specimen very well preserved with body and wings (Figure 3); body about $7 \mathrm{~mm}$ long, including head and rostrum. Rostrum slightly longer than palpus; head almost 1.3 times wider than long; last segment of palpus only slightly shorter than all remaining segment combined together; antenna twice as long as rostrum and 2.5 times as long as a head, 16-segmented, scapus elongated, cylindrical, pedicel short and widen; first flagellomere as long as following ones (Figures 3.2, 4.1); wing about $8 \mathrm{~mm}$ long (Figures 3.4, 4.4), narrow. Vein Sc ends behind forking of Rs; $R_{1}$ reaches outer margin almost opposite $2 / 3$ length of vein $R_{2+3+4}, R_{2+3+4}$ almost twice as long as Rs; $R_{5}$ long, three times longer than Rs, strongly arching and waved at distal part; d-cell big, widen at base; cross-vein $\mathrm{m}-\mathrm{cu}$ in forking $\mathrm{Mb}$. Fore and middle and left hind legs preserved, long, without spines on femur. Hypopygium (Figures 3.2, 4.3) with short and broad gonocoxite, outer gonostylus strongly sclerotized, short, broad at base and gradually narrowing to distal part, shorter than $1 / 3$ of gonocoxite; inner gonostylus as long as outer one, lobe-shape, not sclerotize.

\section{DISCUSSION}

The oldest representative of genus Helius (Limoniidae) is known from the Lebanese amber aged Lower Cretaceous (Krzemiński et al., 2014; Kania et al., 2016). The most obvious evolutionary trend in morphology of the genus Helius concerned the mouthparts (Kania, 2014; Kania et al., 2016). Rostrum of these flies underwent a strong transformation in result of co-evolution with angiosperms, which evolved at the same time. The concept that genus Helius appeared and evolved most probably on the area of Gondwana is supported by the evidence of the two oldest species preserved in Lebanese amber (Kania et al., 2013; Krzemiński et al., 2014) and one from the Upper Cretaceous of Botswana (Rayner and Waters, 1990). These three taxa illustrate evolutionary trends, which dominate in further evolution of genus; $H$. lebanensis Kania, Krzemiński and Azar is characterized by rostrum only slightly exceeding the head width, while the rostrum of the second species of the same age, $H$. ewa Krzemiński, Kania and Azar, is few times longer than width of the head, and reaches ca. 1/3 body length. Comparative head morphology of the already described fossil species from the genus Helius was discussed in Krzemiński et al. (2014) and Kania et al. (2016).

Evolution of the genus Helius was closely connected with the radiation and expansion of angiosperms, and its representatives were known from all geological periods since the Lower Cretaceous on different continents. Well documented diversity in the rostrum among the Cretaceous representatives of Helius indicates a high evolutionary potential and rapid evolution of flies of this taxon (Ribeiro, 2002; Kania, 2014; Krzemiński et al., 2014; Kania et al., 2016).

An investigated specimen, which is one of the youngest impressed fossil representative of the 


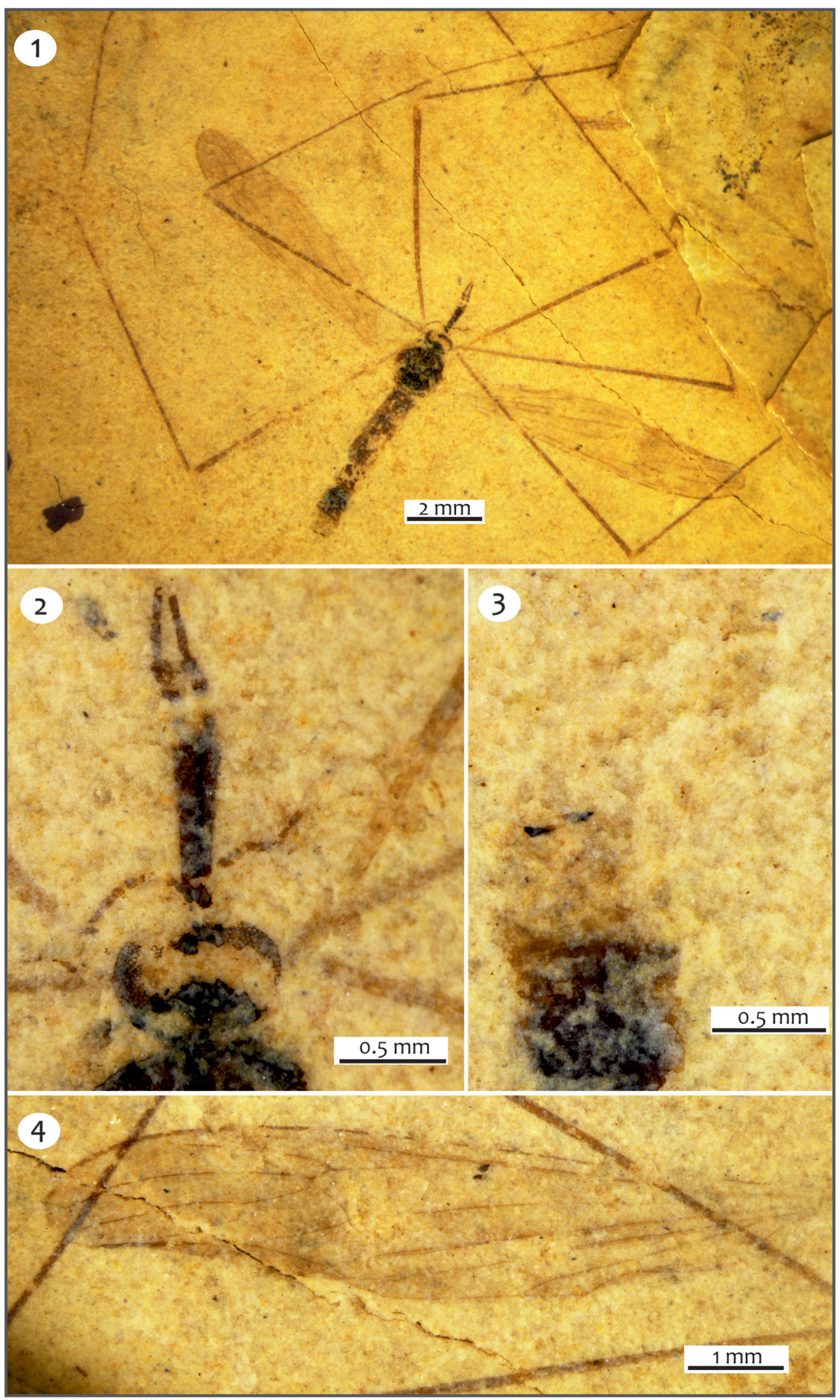

FIGURE 3. Helius (Helius) qinghai n. sp., photography of the holotype No. CNU-DIP-QZ2017001; 1 - body, 2 - male genitalia, 3 - head, 4 - left wing (photo by Siyuan Wu). 


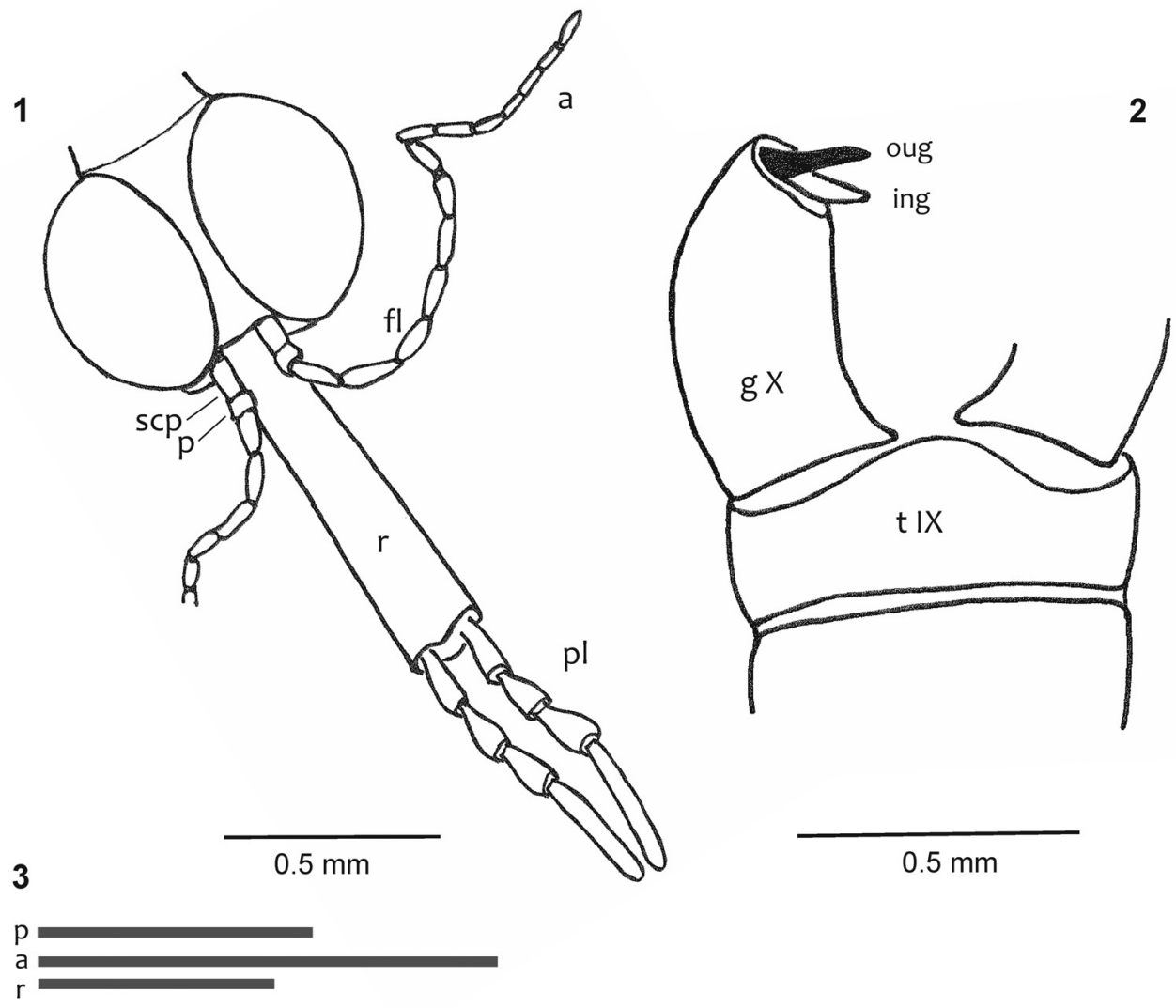

\section{4}

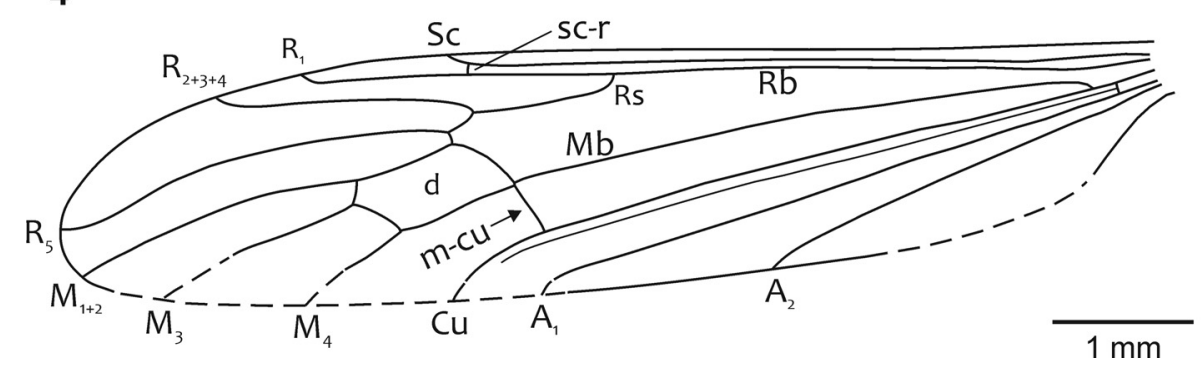

FIGURE 4. Helius (Helius) qinghai $\mathrm{n}$. sp., drawings of the holotype No. CNU-DIP-QZ2017001; 1 - head, 2 - male genitalia, 3 - relation between the length of palpi $(p)$, antenna (a) and rostrum, 4 - wing ( $\mathrm{a}$ - antenna, $\mathrm{fl}-\mathrm{flagel}-$ lomeres, $\mathrm{g}$ - gonocoxite, ing - inner gonostylus, oug - outer gonostylus, $\mathrm{p}$ - pedicel, $\mathrm{pl}$ - palpi, $\mathrm{r}$ - rostrum, scp scapus, $\mathrm{t}-$ tergite) (drawings by W. Krzemiński).

genus (Table 1), was found in the little studied locality from the Guide Group at Caergen Village, Duohemao Town, Zeku County, eastern Qinghai Province, North-west China from early Miocene. Investigations of fossil flora and insects from the family Cixiidae (Hemiptera) from this locality (Guo, 1980; Li Y. et al., 2016) support the concept that the local paleoclimate in the Early Miocene was warm-temperate, mild and arid, and the area was overgrown by wood and shrubs.
The newly described species, Helius qinghai sp. nov., is large; its wings reach almost $8 \mathrm{~mm}$. Wings of other fossil congeners are $2.5-7 \mathrm{~mm}$ long, while those of most recent taxa are not longer than $10 \mathrm{~mm}$. Ratios of the length of rostrum, antenna and palpi characteristic for a new species resemble slightly those of $H$. oosterbroeki Kopeć, Kania and Krzemiński, 2016 described from Dominican amber (Lower Miocene). However, the latter species is half as large, with wings only $4 \mathrm{~mm}$ long, and comes from a different region of the world. 
Moreover, these two species differ in wing venation and male genitalia (Kopeć et al., 2016). Therefore, this similarity in proportion of mouthparts of $H$. qinghai and $H$. oosterbroeki is considered to be incidental. The differences from the remaining fossil congeners of $H$. $(H$.) qinghai sp. nov. are significant and based mostly on differences in proportion of antenna, palpi and rostrum as well in wings venation and male hypopygium. The finding of the new and one of the youngest representatives of genus Helius enriches our knowledge about the evolution of this genus.

\section{ACKNOWLEDGEMENTS}

This research was supported by the National Natural Science Foundation of China (Nos. 31730087 and 41688103), Program for Changjiang Scholars and Innovative Research Team in University (IRT-17R75) and financially supported by the University of Łódź. We are grateful to $E$. Krzemińska for English correction of the first version of the manuscript.

\section{REFERENCES}

Alexander, C.P. 1931. Crane-flies of the Baltic amber (Diptera). Bernstein-Forschungen, 2:1-135.

Fang, X.,Yan, M., Van der Voo, R., Rea, D.V., Song, C.,Parés, Gao, J., Nie, J, and Dai, S.2005. Late Cenozoic deformation and uplift of the NE Tibetan Plateau: Evidence from high resolution magnetostratigraphy of the guide basin, Qinghai province, China. Geological Society of America Bulletin, 117:1208-1225. https://doi.org/10.1130/B25727.1

Guo, S.X. 1980. Miocene flora in Zeku county of Qinghai. Acta Palaeontologica Sinica, 19:406412.

Kania, I. 2014. Subfamily Limoniinae Speiser, 1909 (Diptera, Limoniidae) from Baltic amber (Eocene): the genus Helius Lepeletier \& Serville, 1828. Zootaxa, 3814:333-352. http:// dx.doi.org/10.11646/zootaxa.3814.3.2

Kania, I., Krzemiński, W., and Arillo, A. 2016. First representative of the genus Helius Lepeletier and Serville, 1828 (Diptera, Limoniidae) from the Lower Cretaceous Álava amber (Spain). Cretaceous Research, 63:33-38. https://doi.org/10.1016/j.cretres.2016.02.018

Kania, I., Krzemiński, W., and Azar, D. 2013. The oldest representative of Helius Lepeletier \& Serville 1828 (Limoniidae, Diptera) from Lebanese amber (Early Cretaceous). Insect Systematics \& Evolution, 44:1-8. https://doi.org/10.1163/1876312x-44032093

Kopeć, K., Kania, I., and Krzemiński, W. 2016. New and little known crane-fly species of the genera Helius, Elephantomyia and Toxorhina (Diptera, Limoniidae) from Dominican and Mexican amber. Palaeontologia Electronica 19.2.25A:1-14. https://doi.org/10.26879/593 https://palaeo-electronica.org/content/2016/1535-a-new-limoniidae-from-miocene

Krzemińska, E., Krzemiński, W., and Dahl, C. 2009. Monograph of fossil Trichoceridae (Diptera) over 180 million years of evolution. Institute of Systematics and Evolution of Animals, Polish Academy of Sciences, Kraków.

Krzemiński, W. 1985. Limoniidae (Diptera Nematocera) from Baltic amber (in the collection of the Museum of the Earth in Warsaw). Part I. Subfamily Limoniinae. Prace Muzeum Ziemi, 37:113-117.

Krzemiński, W. 1991. A first fossil Helius (Diptera, Limoniidae) from North America. Acta Zoologica Cracoviensia, 34:311-313.

Krzemiński, W. 1993. Fossil Tipulomorpha (Diptera, Nematocera) from Baltic amber (Upper Eocene). Revision of the genus Helius Lepeletier et Serville (Limoniidae). Acta Zoologica Cracoviensia, 35:597-601.

Krzemiński, W. 2002. Three new species of the genus Helius Lepeletier \& Serville (Diptera, Limoniidae) from the Middle Miocene of Stavropol (northern Caucasus, Russia). Acta Zoologica Cracoviensia, 45:317-320.

Krzemiński, W., Kania, I., and Azar, D. 2014. The Early Cretaceous evidence of rapid evolution of the genus Helius Lepeletier\& Serville 1828 (Limoniidae, Diptera). Cretaceous Research, 48:96-101. https://doi.org/10.1016/j.cretres.2013.12.001

Lepeletier, A.L.M. and Serville, J.G.A. 1828. Entomologie, ou histoire naturelle des crustacés, des arachnides et des insectes. Encyclopedie Méthodique, Histoire Naturelle, 10:345-833. 
Li, Y., Liu, X., Ren, D., Li, X., and Yao, Y. 2016. First report of Cixiidae insect fossils from the Miocene of the northeastern Tibetan Plateau and their palaeoenvironmental implications. Alcheringa, 41:54-60. https://doi.org/10.1080/03115518.2016.1180027

Li, X., Xiao, L., Lin, Z., He, W., Yang, Q., Yao, Y., Ren, D., Guo, J., and Guo, S. 2016. Fossil fruits of Koelreuteria (Sapindaceae) from the Miocene of northeastern Tibetan Plateau and their palaeoenvironmental, phytogeographic and phylogenetic implications. Review of Palaeobotany and Palynology, 234:125-135. https://doi.org/10.1016/j.revpalbo.2016.09.002

Linnaeus, C.1758. Systema nature per regna tria naturae, secundum classes, ordines, genera, species, cum caracteribus, differentiis, synonymi, locis. Tomus I. Editio decima, reformata. L. Salvii, Holmiae [= Stockholm], pp. 824. https://doi.org/10.5962/bhl.title.542

Loew, H. 1850. Über den Bernstein und die Bernsteinfauna. Program der Keiserischen Realschule Meseritz, 1:3-44. (in German) https://doi.org/10.5962/bhl.title.98386

Meigen, J.W. 1818. Systematische Beschreibung der bekannten europäischen zweiflügeligen Insecten. Erster Theil. F.W. Forstmann, Aachen. https://doi.org/10.5962/bhl.title.13731

Meunier, F. 1906. Monographie des Tipulidae et des Dixidae de l'ambre de la Baltique. Annales des Science Naturelle Zoologie, 4:349-401.

Oosterbroek, P. 2016. Catalogue of the Crane-flies of the World. (Diptera, Tipuloidea: Pediciidae, Limoniidae, Cylindrotomidae, Tipulidae). https://ccw.naturalis.nl/index.php. Last updated 10 October 2018.

Podenas, S. 2002. New species of Helius crane flies (Diptera: Limoniidae) from Baltic amber (Eocene). Mitteilungenausdem Geologisch-Paläontologischen Institut der Universität Hamburg, 86:229-238.

Podenas, S. and Poinar, G.O. 2001. New crane flies (Diptera: Tipulidae, Limoniidae) from Dominican and Mexican amber. Proceedings of the Entomological Society of Washington, 104(4):863-878.

Podenas, S. and Poinar, G.O. 2012. New short-palped crane flies (Diptera: Limoniidae) from Mexican amber. Proceedings of the Entomological Society of Washington, 114(3):347-371. https://doi.org/10.4289/0013-8797.114.3.347

Qiu Z., Li C. and Wang, S. 1981b. Miocene mammal fossils from Xining Basin, Qinghai. Vertebrata Palasiatica,19:156-173. (In Chinese)

Qiu, Z., Li C. and Wang, S. 1981a. Discussion on Miocene stratigraphy and mammals from Xining Basin, Qinghai. Vertebrata Palasiatica, 19:313-320. (In Chinese)

Rayner, R.J. and Waters, S.B. 1990. A Cretaceous crane-fly (Diptera: Tipulidae): 93 million years of stasis. Zoological Journal of the Linnean Society, 99:309-318. https://doi.org/10.1111/ j.1096-3642.1990.tb00557.x

Ribeiro, G.C. 2002. A new fossil Helius (Diptera, Limoniidae) from Burmese amber. Studia Dipterologica, 9:403-408.

Speiser, P. 1909. 10. Diptera. 4. Orthorapha. Orthorapha Nematocera. Wissenschaftliche Ergebnisse der Schwedischen Zoologische Expededition nach Kilimandjaro, Meru 10 (Diptera):31-65.

Statz, G. 1944. New Dipteren (Nematocera) ausdem Oberoligocän von Rott. III. Familie Limnobiidae (Stelzmücken). IV. Familie: Tipulidae (Schnaken). V. Familie: Culicidae (Stechmücken). Palaeontographica(A), 95:93-120.

Sun, X., Zhao, Y., and He, Z. 1984. The Oligocene Miocene palynological assemblages from the Xining Minhe Basin. Geological Review, 30:207-216. (in Chinese) 